\title{
Updated indicators of Swedish national human toxicity and ecotoxicity footprints using USEtox 2.01
}

\author{
Maria Nordborg ${ }^{\mathrm{a}, *}$, Rickard Arvidsson ${ }^{\mathrm{b}}$, Göran Finnveden ${ }^{\mathrm{c}}$, Christel Cederberg ${ }^{\mathrm{a}}$, Louise Sörme ${ }^{\mathrm{d}}$, \\ Viveka Palm ${ }^{\mathrm{c}, \mathrm{d}}$, Kristin Stamyr ${ }^{\mathrm{c}}$, Sverker Molander ${ }^{\mathrm{b}}$ \\ a Division of Physical Resource Theory, Department of Energy and Environment, Chalmers University of Technology, SE-412 96 Gothenburg, Sweden \\ ${ }^{\mathrm{b}}$ Division of Environmental Systems Analysis, Department of Energy and Environment, Chalmers University of Technology, SE-412 96 Gothenburg, Sweden \\ c KTH Royal Institute of Technology, Division of Environmental Strategies Research, SE-100 44 Stockholm, Sweden \\ d Statistics Sweden, Regions and Environment Department, SE-104 51 Stockholm, Sweden
}

\section{A R T I C L E I N F O}

\section{Article history:}

Received 24 April 2016

Received in revised form 18 July 2016

Accepted 18 August 2016

Available online xxxx

\section{Keywords:}

Chemical footprint

USEtox

Ecotoxicity

Human toxicity

Zinc

E-PRTR

\begin{abstract}
A B S T R A C T
In a recent paper, Sörme et al. (Environ. Impact Assess. Rev., 56, 2016), took a first step towards an indicator of a national chemical footprint, and applied it to Sweden. Using USEtox 1.01, they calculated national impact potentials for human toxicity and ecotoxicity. The results showed that zinc dominated impacts, both for human toxicity and ecotoxicity. We calculated updated indicators of the Swedish national human toxicity and ecotoxicity footprint using USEtox 2.01. We also compared impact potentials based on USEtox with the mass of chemical emissions. The two model versions produced relatively consistent results. Zinc is still a major contributor to the human toxicity and ecotoxicity impact potentials when characterized with USEtox 2.01 . The mass-based indicator pinpoints somewhat different substances than the impact-based indicators.
\end{abstract}

(c) 2016 Published by Elsevier Inc.

\section{Introduction}

In a recent paper, Sörme et al. (2016) took a first step towards an indicator of a national chemical footprint, and applied it to Sweden. A definition of "environmental footprints" has been suggested as "metrics used to report life cycle assessment results addressing an area of concern", and they are primarily intended for communication with the society and non-technical stakeholders (Ridoutt et al., 2016). Using data from the European Pollutant Release and Transfer Register (E-PRTR) on emissions to air and water from Swedish point sources in 2008, and characterization factors (CFs) from the USEtox 1.01 model (Rosenbaum et al., 2008; Hauschild et al., 2008), Sörme et al. (2016) calculated aggregated national impact potentials for human toxicity and ecotoxicity.

The results showed that zinc contributed most to the impact potentials both for human toxicity (68\%), and ecotoxicity (63\%). Other similar studies have also identified zinc as a priority substance. Bjørn et al. (2014) developed a chemical footprinting method that estimates the dilution needed to avoid ecosystem damage, based on CFs from USEtox 1.01. When applying this method to emissions in Europe in 2004, zinc and copper were identified as the substances with largest contribution (70\%, and $30 \%$ respectively) to the ecotoxicity impact potential. In

\footnotetext{
* Corresponding author.

E-mail addresses: maria.nordborg@chalmers.se, maria.nordborg@gmail.com (M. Nordborg).
}

another chemical ecotoxicity footprinting study for Europe, using CFs from USEtox 1.01, zinc was also a major contributor, along with some other metals and pesticides (Sala and Goralczyk, 2013).

It is well established that zinc can cause ecotoxicity impacts on freshwater organisms (Eisler, 1993). For example, van Genderen et al. (2009) compiled data on zinc concentrations in streams and lakes in Europe, North America and South America, and found that $17 \%$ of 834 assessed sites had zinc concentrations in excess of ecotoxicity thresholds (no observable effect concentration for Daphnia magna and 10\% effective concentrations for growth rate for Pseudokirchneriella subcapitata).

The ability of zinc to cause toxic impacts to humans is less established. The World Health Organization (WHO) does not include zinc in its list of chemicals of major public health concern, but mentions, among others, cadmium, benzene, arsenic, lead and mercury (WHO, 2010). Likewise, a recent review of global burden of disease estimates from chemicals mentioned among others indoor smoke from solid fuel combustion, second-hand smoke, outdoor air pollutants (particulate matter, benzo[a]pyrene, benzene, etc.), lead, and chemicals involved in acute poisonings (drugs, pesticides, etc.), but not zinc (Prüss-Ustün et al., 2011). For humans, as well as for other organisms, zinc is an essential trace element. A review on the impact of zinc on human health concluded that zinc is "relatively harmless", and that zinc deficiency is a far greater problem than zinc intoxication (Plum et al., 2010). The zinc dominance in national human health impact assessments based on USEtox 1.01, and the lack of reports of adverse human 
health impacts associated with zinc, opens the question about the appropriateness of the CFs from USEtox 1.01.

One of the environmental objectives adopted by the Swedish Government is "A Non-Toxic Environment". According to another objective, the Generation Goal, a non-toxic environment should be achieved without increasing impacts in other countries (www.miljomal.se). To monitor these multiple objectives, reliable and feasible methods are needed that can indicate the (eco)toxic impacts associated with (Swedish) consumption, over time. National chemical footprinting methods can identify, e.g., which substances are of largest concern and trends over time. Such information is important from a chemical management perspective, and could be used by decision makers for regulatory purposes. It should however be noted that other indicators of chemical pollution might also be of interest, e.g., the number of commercially available chemicals, or the annual emissions of single, groups of, or all chemicals. For more examples of indicators of chemical drivers, pressures, state and impacts, see Diamond et al. (2015).

In August 2015, a new, updated version of USEtox was released: USEtox 2.0 (Fantke et al., 2015a). Important new features include human exposure to pesticide residues in crops; an indoor air compartment for human exposure through inhalation, and improved fate and effect modeling of metals. The two model versions have been compared in a study of the human health impacts from land application of sewage sludge (Harder, 2015), and found to yield relatively consistent results. In February 2016, a "corrective update" of the USEtox model was released: USEtox 2.01 (www.usetox.org), due to "technical problems with correctly referencing equations for calculating inorganic characterization factors" in USEtox 2.0 (Fantke, 2016). No comparisons between USEtox 1.01 and 2.01 has yet been published.

The aim of this study is to re-calculate the national impact potentials for human toxicity and ecotoxicity associated with Swedish point source emissions in 2008, using USEtox 2.01, and compare with the corresponding impact potentials in Sörme et al. (2016), calculated with USEtox 1.01. In particular, we will investigate if zinc still dominates when emissions are characterized with USEtox 2.01, instead of 1.01 . We will also compare the USEtox 2.01 and 1.01 impact potentials with the mass of chemical emissions, which is another, albeit more simplistic, possible indicator of national chemical pollution.

\section{Materials and methods}

We applied the method described in Sörme et al. (2016) and calculated national impact potentials for human toxicity and ecotoxicity associated with emissions from Swedish point sources in 2008, with the difference that we used CFs from USEtox 2.01, instead of 1.01. Following Sörme et al. (2016), national impact potentials for human toxicity and ecotoxicity were calculated by multiplying the emission $(E)$ of a substance $(i)$ by its $\mathrm{CF}$, and summarizing the impacts across all substances and emission compartments $(j)$ (Eq. 1).

Impact potential $=\sum_{i, j} E_{i, j} \times C F_{i, j}$

Impact potentials are measured in Comparative Toxic Units for human health (CTUh) and ecotoxicity (CTUe), respectively. It should be noted that the size of the human toxicity and ecotoxicity impact potentials are not comparable, since they are measured in different units. CFs were obtained from the USEtox 2.01 model, downloaded from the USEtox website (www.usetox.org). USEtox 2.01 CFs are classified as "recommended" or "indicative", which corresponds to "interim" in USEtox 1.01. Indicative CFs are associated with considerable uncertainties. Both recommended and indicative CFs were used in the calculations.

We used the same emission data as in Sörme et al. (2016), i.e., emissions to air and water from Swedish point sources in 2008, as reported to the E-PRTR. Substances which were not characterized in Sörme et al. (2016), due to lack of CFs in USEtox 1.01, were in contrast included here if CFs were available in USEtox 2.01 (this was the case for the following substances: benzo(g,h,i)perylene, dichloromethane, trichloromethane and tetrachloromethane for human toxicity, and dichloromethane, PCDD + PCDF (dioxins + furans), trichloromethane and tetrachloromethane for ecotoxicity; see Table S1, Supplementary material).

In total, 25 substances were characterized in this study, compared to 21 in Sörme et al. (2016). This can be compared with 50 substances with non-zero emissions ( to either air or water) in E-PRTR for Sweden (Table S1, Supplementary material). Examples of substances (with emissions $>5000 \mathrm{~kg} \mathrm{yr}^{-1}$ ) which could not be characterized due to lack of CFs in USEtox 2.01 include particulate matter, nitrogen oxides, sulphur oxides, chlorides, flourides and cyanides. Some of these substances are highly relevant from an (eco)toxicological perspective (such as cyanides, see e.g., Cummings, 2004), for which reason it is problematic that CFs are not available, while other substances are less of a concern.

We used the same assumptions when calculating (eco)toxicity impact potentials as used in Sörme et al. (2016). For example, emissions to water were assumed to be to freshwater, and the highest CFs for substances were chosen if there was a choice (for more information, see Tables 1 and 2). Note that Sörme et al. (2016) differentiated between the air and freshwater emission compartments for human toxicity, but combined both emission compartments for ecotoxicity, while we combined both emission compartments for both human toxicity and ecotoxicity. Also note that impact potentials in Sörme et al. (2016) were reported in units different from those used here, due to a mistake in Rosenbaum et al. (2008), in which it was stated that CFs are expressed in the unit CTUe, instead of CTUe $\mathrm{kg}^{-1}$, which is correct.

The work reported here thus essentially constitutes a re-calculation of the impact potentials reported by Sörme et al. (2016), and the results represent updated national impact potentials for human toxicity and ecotoxicity, due to emissions from Swedish point sources in 2008. We did not repeat the input-output analysis part of the method that allocates impacts to product groups.

\section{Results}

\subsection{Human toxicity}

Human toxicity impacts decreased by 33\%, from 720 CTUh, based on characterization with USEtox 1.01, to 480 CTUh, based on characterization with USEtox 2.01 (Table 1). Notably, both versions of USEtox identify the same set of five substances with largest contribution to the human toxicity impact potential, although the ranking differs somewhat. In particular, both versions of USEtox attribute the largest impact potentials to zinc, followed by mercury. However, USEtox 2.01 attributes a smaller potential impact to zinc, and a larger potential impact to mercury, compared to USEtox 1.01 .

Both model versions identify metals as a priority group of substances from a human health perspective, but the contribution of metals to the human toxicity impact potential decreased slightly, from $99 \%$ based on characterization with USEtox 1.01, to $93 \%$ based on characterization with USEtox 2.01. In particular, zinc decreased its contribution to the human toxicity impact potential from $68 \%$ in Sörme et al. (2016), to 34\% here.

Inclusion of substances which were not characterized in Sörme et al. (2016), did not significantly affect the results. Together, they contribute $0.01 \%$ to the aggregated human toxicity impact potential. It should be noted that eight out of eleven substances in Table 1 were characterized with indicative $\mathrm{CFs}$.

\subsection{Ecotoxicity}

Ecotoxicity impacts increased by a factor of 20, from 6.3E +9 CTUe, based on characterization with USEtox1.01, to $1.3 \mathrm{E}+11$ CTUe, based on characterization with USEtox 2.01 (Table 2). The main reason is that the ecotoxicity impact potential associated with copper increased by 3 orders of magnitude. Considering the top five substances with largest contribution to the aggregate impact potential, three substances - 
Table 1

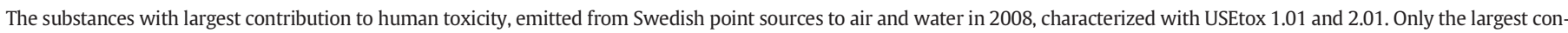

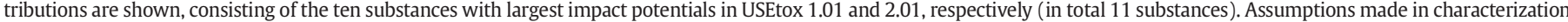
are given in the table footnotes, and follow Sörme et al. (2016). Substances marked with * have indicative characterization factors in both model versions.

\begin{tabular}{|c|c|c|}
\hline \multirow{2}{*}{$\begin{array}{l}\text { Substances (as given in the E-PRTR) ranked based on this study } \\
\text { (ranking in Sörme et al., } 2016 \text { in parenthesis). }\end{array}$} & \multicolumn{2}{|c|}{ Impact potential (CTUh), and contribution to impact (\%) } \\
\hline & USEtox 2.01 (this study) & USEtox 1.01 (Sörme et al., 2016) \\
\hline Zinc and compounds (as Zn) $)^{\mathrm{a}}(1)^{*}$ & $1.6 \mathrm{E}+02,34 \%$ & $4.9 \mathrm{E}+02,68 \%$ \\
\hline Mercury and compounds (as Hg) ${ }^{b}(2)^{*}$ & $1.4 \mathrm{E}+02,29 \%$ & $9.2 \mathrm{E}+01,13 \%$ \\
\hline Lead and compounds $(\mathrm{as} \mathrm{Pb})^{\mathrm{c}}(5)^{*}$ & $4.7 \mathrm{E}+01,10 \%$ & $2.8 \mathrm{E}+01,4 \%$ \\
\hline Chromium and compounds (as $\mathrm{Cr})^{\mathrm{d}}(3)^{*}$ & $4.6 \mathrm{E}+01,9 \%$ & $5.4 \mathrm{E}+01,8 \%$ \\
\hline Arsenic and compounds (as As) $)^{\mathrm{e}}(4)^{*}$ & $4.5 \mathrm{E}+01,9 \%$ & $4.8 \mathrm{E}+01,7 \%$ \\
\hline Polycyclic aromatic hydrocarbons $(\mathrm{PAHs})^{\mathrm{f}}(9)^{*}$ & $3.2 \mathrm{E}+01,7 \%$ & $2.6 \mathrm{E}-01,<1 \%$ \\
\hline Cadmium and compounds (as Cd) ${ }^{\mathrm{g}}(7)^{*}$ & $6.9 \mathrm{E}+00,1 \%$ & $3.1 \mathrm{E}+00,<1 \%$ \\
\hline Non-methane volatile organic compounds $(\mathrm{NMVOC})^{\mathrm{h}}(6)$ & $2.5 \mathrm{E}+00,1 \%$ & $3.6 \mathrm{E}+00,<1 \%$ \\
\hline Nickel and compounds $(\text { as } \mathrm{Ni})^{\mathrm{i}}(8)^{*}$ & $1.2 \mathrm{E}+00,<1 \%$ & $4.1 \mathrm{E}-01,<1 \%$ \\
\hline Fluoranthene (11) & $7.6 \mathrm{E}-01,<1 \%$ & $3.2 \mathrm{E}-02,<1 \%$ \\
\hline Halogenated organic compounds (as AOX) ${ }^{\mathrm{j}}(10)$ & $2.1 \mathrm{E}-01,<1 \%$ & $2.4 \mathrm{E}-01,<1 \%$ \\
\hline Total (all substances) & $4.8 \mathrm{E}+02,100 \%$ & $7.2 \mathrm{E}+02,100 \%$ \\
\hline
\end{tabular}

a As $\mathrm{Zn}(\mathrm{II})$.

b As $\mathrm{Hg}(\mathrm{II})$.

c As $\mathrm{Pb}(\mathrm{II})$.

d As $\mathrm{Cr}(\mathrm{VI})$.

e $\mathrm{As} \mathrm{As}(\mathrm{V})$.

f As benzo[a]pyrene.

g As Cd(II).

h As benzene.

i As Ni(II).

j As 1,4-dichlorobenzene.

ranked differently - are identified by both model versions (copper, zinc, and flouranthene), while the other two substances differ between the model versions.

Both USEtox 1.01 and 2.01 identify metals as a priority group of substances from an ecotoxicological perspective. The contribution of metals increased from $77 \%$ of the ecotoxicity impact potential based on characterization with USEtox 1.01, to $99 \%$ based on characterization with USEtox 2.01. In relative terms, zinc decreased its contribution to the ecotoxicity impact potential from 63\% in Sörme et al. (2016), to $10 \%$ here, while in absolute terms, the impact potential associated with zinc increased by roughly a factor of 3 .

Inclusion of substances which were not characterized in Sörme et al. (2016), did not significantly affect the results. Together, they contribute $\ll 1 \%$ to the aggregated ecotoxicity impact potential. It should be noted that six out of ten substances in Table 2 were characterized with indicative CFs.

\section{Discussion}

The two USEtox versions are relatively consistent in identifying the substances with largest contribution to the aggregated impact potentials, both for human toxicity and ecotoxicity. Increased ecotoxicity impact potentials of cadmium, copper, nickel and zinc, by up to 2 order of magnitude, are most probably associated with improved modeling of speciation, bioavailability and freshwater chemistry, as described in Dong et al. (2014), possibly in combination with updated ecotoxicological effect data and updated extrapolation factors from acute to chronic effect, as described in Fantke et al. (2015b). In particular, the partitioning of metals between different environmental media (suspended solids, water, sediment particles and soil particles) have been updated to better reflect the truly dissolved fraction in freshwater. Since a detailed description of the updates in USEtox 2.01, and comparisons to results from USEtox 1.01, have not yet been published, it is difficult at this

Table 2

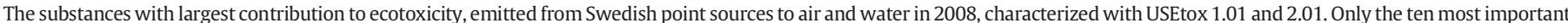

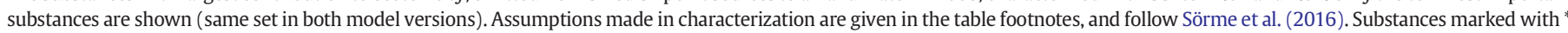
have indicative characterization factors in both model versions.

\begin{tabular}{|c|c|c|}
\hline \multirow{2}{*}{$\begin{array}{l}\text { Substances (as given in the E-PRTR) ranked based on this study } \\
\text { (ranking in Sörme et al., } 2016 \text { in parenthesis) }\end{array}$} & \multicolumn{2}{|c|}{ Impact potential (CTUe), and contribution to impact (\%) } \\
\hline & USEtox 2.01 (this study) & USEtox 1.01 (Sörme et al., 2016) \\
\hline Copper and compounds (as $\mathrm{Cu})^{\mathrm{a}}(3)^{*}$ & $1.1 \mathrm{E}+11,85 \%$ & $6.4 \mathrm{E}+08,10 \%$ \\
\hline Zinc and compounds (as $\mathrm{Zn})^{\mathrm{b}}(1)^{*}$ & $1.4 \mathrm{E}+10,10 \%$ & $4.0 \mathrm{E}+09,63 \%$ \\
\hline Nickel and compounds $(\text { as } \mathrm{Ni})^{\mathrm{C}}(6)^{*}$ & $2.3 \mathrm{E}+09,2 \%$ & $1.2 \mathrm{E}+08,2 \%$ \\
\hline Cadmium and compounds (as $\mathrm{Cd})^{\mathrm{d}}(10)^{*}$ & $1.2 \mathrm{E}+09,1 \%$ & $5.3 \mathrm{E}+06,<1 \%$ \\
\hline Fluoranthene (2) & $9.4 \mathrm{E}+08,1 \%$ & $7.9 \mathrm{E}+08,13 \%$ \\
\hline Chromium and compounds (as $\mathrm{Cr})^{\mathrm{e}}(9)^{*}$ & $4.9 \mathrm{E}+08,<1 \%$ & $6.6 \mathrm{E}+06,<1 \%$ \\
\hline Halogenated organic compounds (as AOX) ${ }^{\mathrm{f}}(4)$ & $4.6 \mathrm{E}+08,<1 \%$ & $4.6 \mathrm{E}+08,7 \%$ \\
\hline Anthracene (5) & $1.9 \mathrm{E}+08,<1 \%$ & $1.6 \mathrm{E}+08,3 \%$ \\
\hline Arsenic and compounds (as As) $)^{g}(7)^{*}$ & $6.4 \mathrm{E}+07,<1 \%$ & $6.6 \mathrm{E}+07,1 \%$ \\
\hline Polycyclic aromatic hydrocarbons (PAHs) ${ }^{\mathrm{h}}(8)$ & $4.9 \mathrm{E}+07,<1 \%$ & $3.4 \mathrm{E}+07,1 \%$ \\
\hline Total (all substances) & $1.3 \mathrm{E}+11,100 \%$ & $6.3 \mathrm{E}+9,100 \%$ \\
\hline
\end{tabular}

\footnotetext{
a As $\mathrm{Cu}(\mathrm{II})$.

b As Zn(II).

c As Ni(II).

d As Cd(II).

e As $\mathrm{Cr}(\mathrm{VI})$.

f As 1,4-dichlorobenzene.

g $\mathrm{As} \mathrm{As}(\mathrm{V})$.

$\mathrm{h}$ As benzo[a]pyrene.
} 
stage to explain the reasons for the observed differences. Studies comparing USEtox 1.01 and 2.01, together with full documentation, will be published on http://usetox.org.

It should be noted that the recommended CFs for organic substances have an estimated uncertainty range of up to 2 and 3 orders of magnitude for ecotoxicity and human toxicity, respectively, primarily related to input data (Rosenbaum et al., 2008). These uncertainties are not considered in our calculations.

Since the metals were identified as a priority group of substances for both human toxicity and ecotoxicity, it should be noted that all metal CFs are classified as "indicative" in both model versions. Their associated uncertainties have not been quantified, but are larger than the uncertainties associated with organic substances, considering that USEtox is primarily developed for organic substances (Rosenbaum et al., 2008). Some fundamental differences between organic and inorganic substances make generic fate, exposure and effect modeling more challenging for metals than for organic substances (Fairbrother et al., 2007; Gandhi et al., 2011a, 2011b; Owsianiak et al., 2013; Dong et al., 2014; Fantke et al., 2015b). For example, while substance-specific physicochemical properties fairly well predict the transport behavior of organic substances, local environmental properties (e.g., pH) determine the transport behavior of metals to a larger extent. In addition, metals speciate into several different forms, which influence fate, exposure and (eco)toxicity characteristics. Moreover, while metals are not degraded, they are made unavailable for living organisms through advection, sedimentation and other processes which are more complex and difficult to model than degradation rates of organic substances (Gandhi et al., 2011a).

Despite the challenges associated with assessing the (eco)toxicity impacts of metals, it is not unreasonable that metals constitute a notable share of the national human toxicity impact potential, as suggested by non-LCA studies (WHO, 2010; Prüss-Ustün et al., 2011). Although these studies are not entirely comparable to our study (concerning differences in scope and methods), it is worth mentioning that some metals that we identified as important from a human health perspective (arsenic, cadmium, lead and mercury), also are recognized as being of "major public health concern" by WHO (2010).

The method applied here uses the mass of chemical emissions in combination with CFs from USEtox to estimate an indicator of a national chemical footprint. A more simplistic indicator of chemical pollution is the mass of chemical emissions. Mass-based indicators should not be considered alternatives to (eco)toxicity impact potentials since they do not take into account the fate, exposure and effect of substances. In fact, simply considering the masses of chemical emissions can be very misleading since mass is not an adequate proxy of (eco)toxicity impacts, see e.g., Nordborg et al. (2014). It should be noted that mass-based indicators of chemical pollution are indicators of pressure, while impact potentials based on USEtox are indicators of impact, in the Driver-Pressure-State-Impact-Response (DPSIR) framework (see e.g., Diamond et al., 2015).

However, mass-based indicators of chemical pollution are being used, see e.g., DeVito et al. (2015) and Ranson et al. (2015), primarily because such indicators are easy to compute, communicate, and based on data that are often available (at least for some countries and sectors). Therefore, it is interesting to compare the results based on mass-based indicators and indicators of chemical footprints based on USEtox. Comparing the ranked order of substances using the impact indicator based on USEtox (Tables 1 and 2), and the mass-based emission indicator (Table 3 ) give partly different results. The mass-based indicator identifies nonmethane volatile organic compounds (NMVOC) and halogenated organic compounds as most important; substances which are only ranked as number eight for human toxicity and seven for ecotoxicity, respectively. However, both types of indicators identify zinc as important; third place using the emission-based indicator, compared to first and second place for human toxicity and ecotoxicity, respectively. One reason is obviously that emissions of zinc are high in Sweden (Table 3).

(Eco)toxicity impact assessments of chemicals are typically hampered by lack of data. Therefore, although limited in scope, pollutant

\section{Table 3}

The ten substances with largest emissions to air and water combined, in descending order. Only substances that were characterized in this study for either human toxicity (marked with *), or ecotoxicity (marked with $¥$ ), are included.

\begin{tabular}{|c|c|}
\hline Substance (as given in the E-PRTR) & Emission $\left(\mathrm{kg} \mathrm{yr}^{-1}\right)$ \\
\hline Non-methane volatile organic compounds $(\mathrm{NMVOC})^{*} \ddagger$ & $2.9 \mathrm{E}+07$ \\
\hline Halogenated organic compounds (as AOX)* $\ddagger$ & $4.7 \mathrm{E}+05$ \\
\hline Zinc and compounds (as Zn)* $¥$ & $1.2 \mathrm{E}+05$ \\
\hline Benzene* $\neq$ & $1.0 \mathrm{E}+05$ \\
\hline Dichloroethane-1,2 (DCE)*‡ & $5.3 \mathrm{E}+04$ \\
\hline Vinyl chloride* & $5.0 \mathrm{E}+04$ \\
\hline Naphthalene* $\neq$ & $1.7 \mathrm{E}+04$ \\
\hline Trichloroethylene* $\neq$ & $1.4 \mathrm{E}+04$ \\
\hline Copper and compounds (as $\mathrm{Cu})^{*} \ddagger$ & $1.2 \mathrm{E}+04$ \\
\hline Chromium and compounds (as $\mathrm{Cr})^{*} \neq$ & $9.8 \mathrm{E}+03$ \\
\hline
\end{tabular}

release and transfer registers, such as the E-PRTR, and the United States Environmental Protection Agency's Toxics Release Inventory (TRI), are highly valuable to researchers and policy makers who wish to, e.g., estimate an aggregated national chemical footprint (for other applications, see e.g., DeVito et al., 2015, and Ranson et al., 2015). In order to support more comprehensive assessments, similar registers should be developed for other sectors (e.g., agriculture).

\section{Conclusions}

We conclude that the two model versions produce relatively consistent results. Although the new version of USEtox includes many updates, the ranking of the most important substances is similar. It is also clear that the associated uncertainties are large and should be clearly communicated. Using the mass of chemical emissions as an indicator pinpoints somewhat different substances.

Zinc is still a major contributor to the human toxicity impact potential when characterized with USEtox 2.01 (Table 1). We thus conclude that the paradox that USEtox pinpoints a substance which has been described as "relatively harmless" (Plum et al., 2010), remains, and that more research is needed in order to resolve this paradox.

\section{Acknowledgements}

Valuable comments from Peter Fantke concerning USEtox 2.01 are gratefully acknowledged, as well as funding from the Swedish Environmental Protection Agency to the Policy-Relevant Indicators for Consumption and Environment (PRINCE) project.

\section{Appendix A. Supplementary data}

Supplementary data to this article can be found online at http://dx. doi.org/10.1016/j.eiar.2016.08.004.

\section{References}

Bjørn, A., Diamond, M., Birkved, M., Hauschild, M.Z., 2014. Chemical footprint method for improved communication of freshwater ecotoxicity impacts in the context of ecological limits. Environ. Sci. Technol. 48, 13253-13262.

Cummings, T.F., 2004. The treatment of cyanide poisoning. Occup. Med. 54, 82-85

Devito, S.C., Keenan, C., Lazarus, D., 2015. Can pollutant release and transfer registers (PRTRs) be used to assess implementation and effectiveness of green chemistry practices? A case study involving the toxics release inventory (TRI) and pharmaceutical manufacturers. Green Chem. 17, 2679-2692.

Diamond, M.L., de Wit, C.A., Molander, S., Scheringer, M., Backhaus, T., Lohmann, R. Arvidsson, R., Bergman, Å., Hauschild, M., Holoubek, I., Persson, L., Suzuki, N., Vighi, M., Zetzsch, C., 2015. Exploring the planetary boundary for chemical pollution: supplementary information. Environ. Int. 78, 8-15.

Dong, Y., Gandhi, N., Hauschild, M.Z., 2014. Development of comparative toxicity potentials of 14 cationic metals in freshwater. Chemosphere 112, 26-33.

Eisler, R., 1993. Zinc Hazards to Fish, Wildlife, and Invertebrates: A Synoptic Review. U. S. Fish and Wildlife Service Biological Report 10

Fairbrother, A., Wenstel, R., Sappington, K., Wood, W., 2007. Framework for metals risk assessment. Ecotoxicol. Environ. Saf. 68, 145-227.

Fantke, P.E., 2016. USEtox ${ }^{\circledR}$ Manager. Technical University of Denmark (Personal communication). 
Fantke, P.E., Huijbregts, M.A.J., Margni, M., Hauschild, M.Z., Jolliet, O., Mckone, T.E., Rosenbaum, R.K., Van De Meent, D., 2015a. USEtox 2.0 User Manual (Version 2). http://usetox.org.

Fantke, P.E., Huijbregts, M.A.J., Hauschild, M.Z., Margni, M., Jolliet, O., Mckone, T.E., Van De Meent, D., Rosenbaum, R.K., 2015b. USEtox 2.0 Manual: Inorganic Substances (Version 2). http://usetox.org

Gandhi, N., Diamond, M.L., Huijbregts, M.A.J., Guinée, J.B., Peijnenburg, W.J., Van De Meent, D., 2011a. Implications of considering metal bioavailability in estimates of freshwater ecotoxicity: examination of two case studies. Int. J. Life Cycle Assess. 16 (8), 774-787.

Gandhi, N., Huijbregts, M.A.J., Van De Meent, D., Peijnenburg, W.J., Guinée, J., Diamond, M.L., 2011b. Implications of geographic variability on comparative toxicity potentials of $\mathrm{Cu}, \mathrm{Ni}$ and $\mathrm{Zn}$ in freshwaters of Canadian ecoregions. Chemosphere 82 (2), 268-277.

Harder, R., 2015. Fresh Perspectives on the Assessment of Sewage Sludge Management. Chalmers University of Technology, Gothenburg .

Hauschild, M.Z., Huijbregts, M., Jolliet, O., Macleod, M., Margni, M., Van De Meent, D.V., ROSENBAUM, R.K., MCKONE, T.E., 2008. Building a model based on scientific consensus for life cycle impact assessment of chemicals: the search for harmony and parsimony. Environ. Sci. Technol. 42, 7032-7037.

Nordborg, M., Cederberg, C., Berndes, G., 2014. Modeling potential freshwater ecotoxicity impacts due to pesticide use in biofuel feedstock production: the cases of maize, rapeseed, Salix, soybean, sugar cane, and wheat. Environ. Sci. Technol. 48 (19), 11379-11388.

Owsianiak, M., Rosenbaum, R.K., Huijbregts, M.A., Hauschild, M.Z., 2013. Addressing geographic variability in the comparative toxicity potential of copper and nickel in soils. Environ. Sci. Technol. 47 (7), 3241-3250.

PLUM, L.M., RINK, L., HAASE, H., 2010. The essential toxin: impact of zinc on human health. Int. J. Environ. Res. Public Health 7, 1342-1365.

Prüss-Ustün, A., Vickers, C., Haefliger, P., Bertollini, R., 2011. Knowns and unknowns on burden of disease due to chemicals: a systematic review. Environ. Health 10.

Ranson, M., Cox, B., Keenan, C., Teitelbaum, D., 2015. The impact of pollution prevention on toxic environmental releases from U.S. manufacturing facilities. Environ. Sci. Technol. 49, 12951-12957.

Ridoutt, B.G., Pfister, S., Manzardo, A., Bare, J., Boulay, A.M., Cherubini, F., Fantke, P., Frischknecht, R., HAUSCHILD, M., Henderson, A., Jolliet, O., Levasseur, A., Margni, M. Mckone, T., Michelsen, O., Canals, L.M.I., Page, G., Pant, R., Raugei, M., Sala, S. Verones, F., 2016. Area of concern: a new paradigm in life cycle assessment for the development of footprint metrics. Int. J. Life Cycle Assess. 21, 276-280.

Rosenbaum, R.K., Bachmann, T.M., Gold, L.S., Huijbregts, M.A.J., Jolliet, O., Juraske, R. Koehler, A., Larsen, H.F., Macleod, M., Margni, M., Mckone, T.E., Payet, J., Schuhmacher, M., Van De Meent, D., Hauschild, M.Z., 2008. USEtox-the UNEPSETAC toxicity model: recommended characterisation factors for human toxicity and freshwater ecotoxicity in life cycle impact assessment. Int. J. Life Cycle Assess. 13, 532-546

Sala, S., Goralczyk, M., 2013. Chemical footprint: a methodological framework for bridging life cycle assessment and planetary boundaries for chemical pollution. Integr. Environ. Assess. Manag. 9, 623-632.

Sörme, L., Palm, V., Finnveden, G., 2016. Using E-PRTR data on point sourceemissions to air andwater-first steps towards a national chemical footprint. Environ. Impact Assess. Rev. 56, 102-112.

Van Genderen, E., Adams, W., Cardwell, R., Volosin, J., Santore, R., Rodriguez, P., 2009. An evaluation of the bioavailability and aquatic toxicity attributed to ambient zinc concentrations in fresh surface waters from several parts of the world. Integr. Environ. Assess. Manag. 5, 426-434.

WHO, 2010. Action Is Needed on Chemicals of Major Public Health Concern. World Health Organization, Geneva .

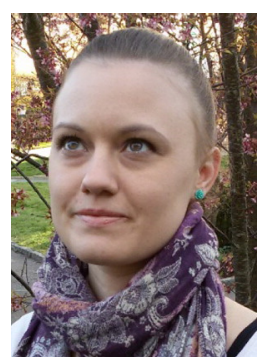

Maria Nordborg is a PhD student at the division of Physical Resource Theory, Department of Energy and Environment, Chalmers University of Technology. Her research aims to expand the knowledge base required to promote sustainable biomass production systems. In previous and ongoing work, she has assessed ecotoxicity impacts from pesticide use in biofuel feedstock production, and in crop production, as well as worked with methods for assessing land use impacts on ecosystem services. Maria holds a MSc in Industrial Ecology, and a BSc in Engineering Physics.

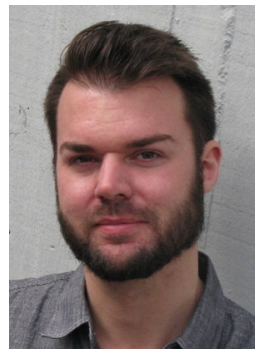

Rickard Arvidsson is an assistant professor at the division of Environmental Systems Analysis at Chalmers University of Technology. His PhD thesis was about environmental risk assessment of nanomaterials. He is currently working with environmental assessments of carbon-based nanomaterials, including graphene. He is also involved in projects related to (eco)toxicity assessment methods in a life cycle perspective.

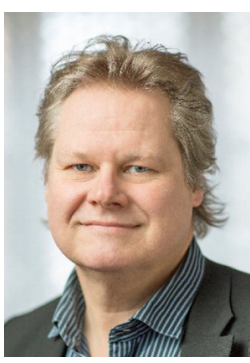

Göran Finnveden is Professor of Environmental Strategic Analysis and Vice-president for sustainable development a KTH Royal Institute of Technology. His main research interest is the use and development of life cycle assessment and other sustainability assessment tools. His contributions include both methodology development and case studies. He also works with environmental policy. Application areas include buildings, consumption, energy, ICT, transportation, urban development and waste management. He is a member of the Swedish Scientific Council for Sustainable Development.

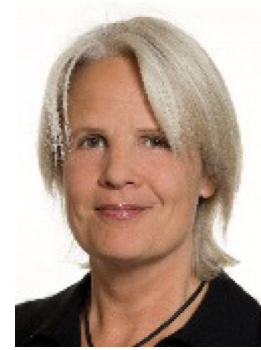

Christel Cederberg, Professor at the Department of Energy and Environment, Chalmers University of Technology, does research in food and environment with emphasis on livestock production systems and land use. She has a long experience of LCA of food commodities, with present focus on ecosystem service assessment in connection with LCA methodology.

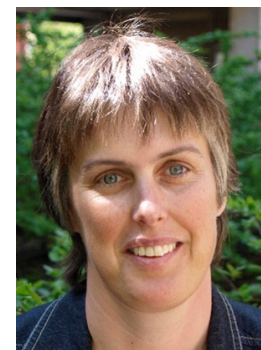

Louise Sörme, $\mathrm{PhD}$, works as a project leader and senior advisor at Statistics Sweden. She has a PhD in Environmental Science from Linköping University, Sweden. She has led and worked in various projects concerning chemicals and waste at Statistics Sweden since 2007. She is involved in several projects to improve Swedish data on emissions to air and water according to the European Pollutant and Transfer Register (E-PRTR). These projects were commissioned by the Swedish Environmental Protection Agency. She is also working in different research projects with Linnaeus University, Sweden, which have been ongoing for several years.

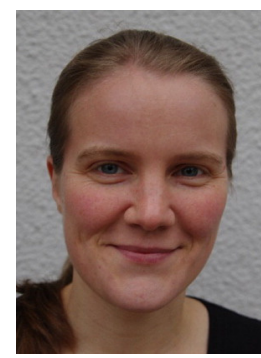

Viveka Palm is an Adjunct Professor at the Royal Institute of Technology (KTH) in Stockholm and also Deputy Director of the Regions and Environment Department at Statistics Sweden. Her academic interest lies in applied environmental economics and in finding internationally harmonized methods to assess the environmental pressure from the economy. She is involved in developing the UN system of Environmental and Economic Accounts that is now being implemented in the EU. In previous work, she has used data from the Swedish Product Register to analyze the use of chemicals in the Swedish economy.

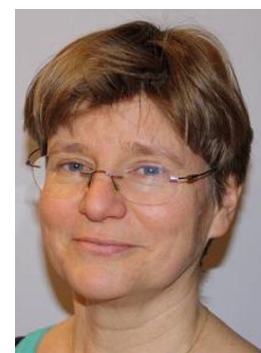

Kristin Stamyr is a researcher at the Division of Environmental Strategies Research (fms) at the Royal Institute of Technologies (KTH), where she works with life cycle assessment (LCA). She has a background in chemical engineering and holds a $\mathrm{PhD}$ in medical science with specialization in toxicology from Karolinska Institutet. Her PhD investigated the possibilities for a rapid diagnose method for cyanide poisoning in fire victims.

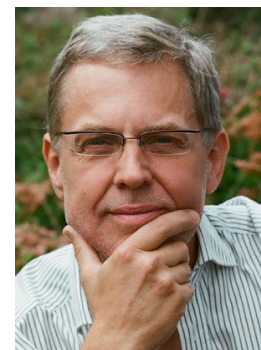

Sverker Molander is Professor with a Chair in Environmental Systems and Risk at Chalmers University of Technology, Sweden. His research covers method development, including indicator construction and models, for use in life-cycle impact assessment, particle and substance flow analysis and environmental and ecological risk assessment. Applications cover organic chemicals, metals, nanomaterials and impacts of renewable energy on ecosystems. He is also applying systems thinking in conjunction to ecosystem services and environmental issues in developing countries. 